\title{
地球環境の保全と微生物
}

\author{
山 中 健 生* \\ * 東京工業大学生命理工学部
}

\section{The Conservation of the Global Environment and Microorganisms}

\author{
Tateo Yamanaka* \\ * Faculty of Bioscience and Biotechnology, \\ Tokyo Institute of Technology
}

\begin{abstract}
The cycles of three elements, nitrogen, sulphur and carbon in the biosphere of the earth have been described with special reference to the bacteria which utilizes the inorganic compounds of the elements.

Ammonia is oxidized to nitrate by a coaction of the ammonia- and nitrite-oxidizing bacteria, the resulting nitrate is changed into nitrogen gas by the denitrifying bacteria. Nitrogen gas is reduced to ammonia by biological and industrial nitrogen fixations. Sulphate is reduced to hydrogen sulphide and this compound is oxidized to elemental sulphur or sulphate by the sulphur-oxidizing bacteria and photosynthetic sulphur-oxidizing bacteria. Finally, carbon dioxide is changed into organic compounds mainly by algae, while the gas is partially reduced to methane by methanogenic bacteria. Methane can be partially trapped by a coaction of the ammonia-oxidizing bacteria and $\mathrm{C}_{1}$ compound-utilizing bacteria.
\end{abstract}

Key words: ammonia-oxidizing bacteria, nitrite-oxidizing bacteria, nitrifying bacteria, denitrifying bacteria, biological nitrogen fixation, sulphate-reducing bacteria, sulphur-oxidizing bacteria, photosynthetic sulphur-oxidizing bacteria.

\section{1.はじめに}

地球上に拈ける窒素, 硫黄, 炭素などの循環には, 微 生物が大きくかかわっている。特に, 独立栄養細菌, つ まり無機物だけで生きてゆける細菌の活動により, 上記 の元素の循環がうまくいっているといえる1),2)。例えば, 窒素の循環は, アンモニアを酸化するアンモニア酸化細 菌, 亜硝酸を酸化する亜硝酸酸化細菌, 硝酸を窒素ガス にする脱窒菌, さらには窒素ガスをアンモニアに還元す る窒素固定細菌の関与によりスムーズに進行する。ま た, 硫黄の循環では, 硫酸還元菌が硫酸塩を硫化水素に 還元し, 硫黄酸化細菌が硫化水素を硫酸に酸化したり, 緑色硫黄細菌や紅色硫黄緑細菌のような光合成硫黄細菌
が硫化水素を元素硫黄や硫酸に酸化する。さらに, 炭素 の循環に执いては，藻類をらくさ緑色植物に負うところ がはなはだ大であるが，またメタンを生成するメタン生 成細菌も重要な存在である。これらのことを表 1 亿まと めてみた。

\section{2. 窒素の循環}

自然界では, 動物の死骸や排出物が腐ったり，植物が 枯れて腐ったりすると,アンモニアが生じる。また, 窒 素肥料として大量の硫安が田畑にあかれアンモニアを供 給する。このようにして自然界に供給されるアンモニア は, 一部分植物比吸収されるが残りはアンモニア酸化細

* =227 横浜市緑区長津田町 4259 (4259 Nagatsuta，Yokohama, 227 Japan)

\section{著者紹介：}

昭和 30 年 大阪大学理学部化学生物学コース卒, 昭和 35 年 大阪大学大学院生物化学専攻博士課程修了, 理学 博士。大阪大学理学部助手, 助教授を経て, 昭和 57 年 東京工業大学理学部教授, 平成 2 年 6 月東京工業大学 生命理工学部教授。生化学, 微生物生理化学, 分子進化学専攻。環境生物地球化学にも興味あり。日本生化学 会, 日本植物生理学会, 日本農芸化学会, 生命の起原拈よび進化学会。 
表 1 自然界に咑㚈窒素，硫黄，炭素の循環に関 与する微生物

\begin{tabular}{|c|c|c|c|}
\hline \multirow{2}{*}{\multicolumn{2}{|c|}{$\begin{array}{l}\text { 循環に関 } \\
\text { する元素 }\end{array}$}} & \multicolumn{2}{|c|}{ 元素の循環に関与する微生物の例 } \\
\hline & & 酸化 & 還 元 \\
\hline \multirow[t]{3}{*}{ 窒 } & 素 & 硝化細菌 & 脱窒菌 \\
\hline & & $\begin{array}{l}\text { Nitrosomonas } \\
\text { europaea }\end{array}$ & $\begin{array}{l}\text { Pseudomonas } \\
\text { aeruginosa }\end{array}$ \\
\hline & & $\begin{array}{l}\text { Nitorobacter } \\
\quad \text { winogradskyi }\end{array}$ & $\begin{array}{c}\text { 窒素固定細菌 } \\
\text { Rhizobium } \\
\text { phaseoli }\end{array}$ \\
\hline \multirow[t]{6}{*}{ 硫 } & 黄 & 硫黄酸化細菌 & 硫酸還元菌 \\
\hline & & $\begin{array}{l}\text { Thiobacillus } \\
\text { thiooxidams }\end{array}$ & $\begin{array}{l}\text { Desulfovibrio } \\
\text { vulgaris }\end{array}$ \\
\hline & & $\begin{array}{l}\text { Thiobacillus } \\
\text { novellus }\end{array}$ & \\
\hline & & 硫黄光合成 (酸化) 細菌 & \\
\hline & & $\begin{array}{l}\text { Chromatium } \\
\text { vinosum }\end{array}$ & \\
\hline & & $\begin{array}{l}\text { Chlorobium } \\
\text { limicola }\end{array}$ & \\
\hline \multirow[t]{4}{*}{ 炭 } & 素 & $\begin{array}{l}\text { （動物）従属栄養 } \\
\text { 細菌など }\end{array}$ & （緑色植物）藻類 \\
\hline & & & メタン生成細菌 \\
\hline & & & $\begin{array}{l}\text { Methanobacterium } \\
\text { autotrophicum }\end{array}$ \\
\hline & & & $\begin{array}{l}\text { 独立栄養光合成細菌 } \\
\text { 独立栄養化学合成細菌 }\end{array}$ \\
\hline
\end{tabular}

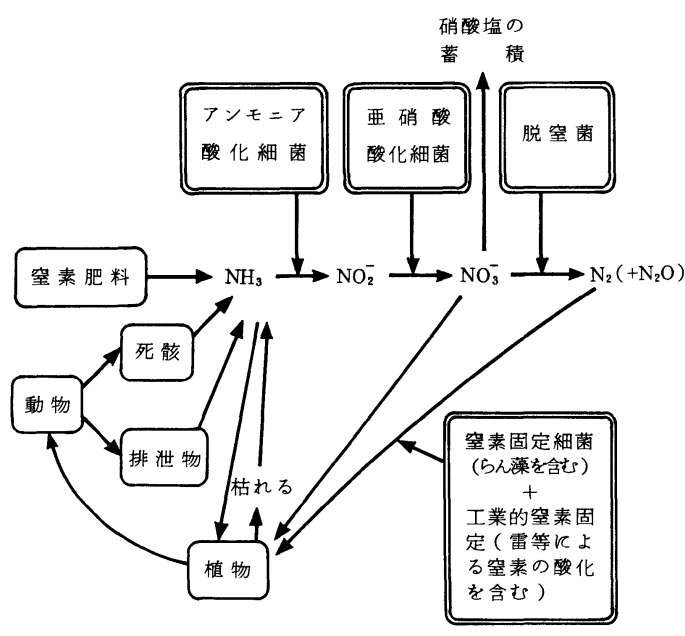

図 1 自然界に打ける窒素の循環 3

菌により覀硝酸に酸化され，さらに覀硝酸酸化細菌によ り硝酸に酸化される。生じた硝酸は一部分植物に吸収さ れるが, 残りは脱窒菌により窒素ガスに還元される。さ らに, 窒素ガスは窒素固定をする細菌によりアンモニア に還元されるほか工業的に硫安などに変化して植物に供 給される(図 1)。ヨーロッパの古い石材建築物では, と ころどころに硝酸塩が付着していることがある。壁の表
面などで硝化細菌（アンモニア酸化細菌と覀硝酸酸化細 菌）によりアンモニアが酸化されて硝酸塩になり蓄積し ているわけで, これは図 1 に示したと抮り窒素の循環か らははみ出していることになる。

\section{1 アンモニア酸化細菌}

アンモニアを亜硝酸に酸化する細菌であり, Nitrosomonas europaea が代表的なものである。N. europaea に拈いては，アンモニアはヒドロキシルアミンを経て亜 硝酸に酸化されることが知られている4)。

アンモニアの酸化を触媒する N. europaea の酵素は, アンモニアモノオキシダナーゼと呼ばれるが, 菌体から 抽出するとすぐに失活するので, この酵素の分子的性質

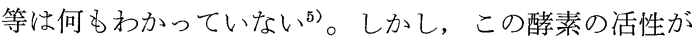
アリルチオ尿素等の銅キレート剂で阻害されることか ら，この酵素は銅酵素だといわれているき。この酵素は， アンモニアに構造が近い, メタン, 一酸化炭素, メタ, ールなどを酸化する7)。中でもメタンの酸化は注目に価 する。というのは, 自然界で, このアンモ二ア酸化細菌 の生育するところでメタンが発生しても，メタンはトラ ップされて空気中へは出ないのである ${ }^{8)}$ (後述)。

アンモニア酸化細菌でもら一つ述べて扣かなければな らないのは, この細菌がアルキルハロゲン化合物, 例え ばクロロエタンやトリクロロエタンを分解する゙9,10)こと である。トリクロロエタンのような有害ハロゲン化合物 を自然界へ放棄することはもちろんやめなければならな いが，かりにあやまってこのような化合物が漏れても， アンモニア酸化細菌が健全な生育をして执れば，かなり な部分がこの細菌により分解される可能性がある。しか し，アンモニア酸化細菌や亜硝酸酸化細菌の健全な生育 を考えるということがあまり注意されていない現状で

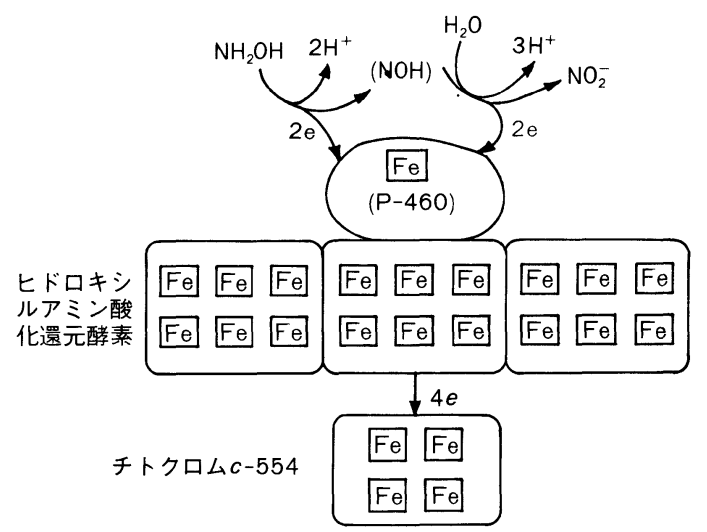

図 2 N. europaea のヒドロキシルアミン酸化還 元酵素の構造の模式的表示およびその機能13) (分子量は 180,000-210,000 で P-460 は3 分子存在するかもしれない) $\mathrm{Fe}=$ 㕕 $c$ 


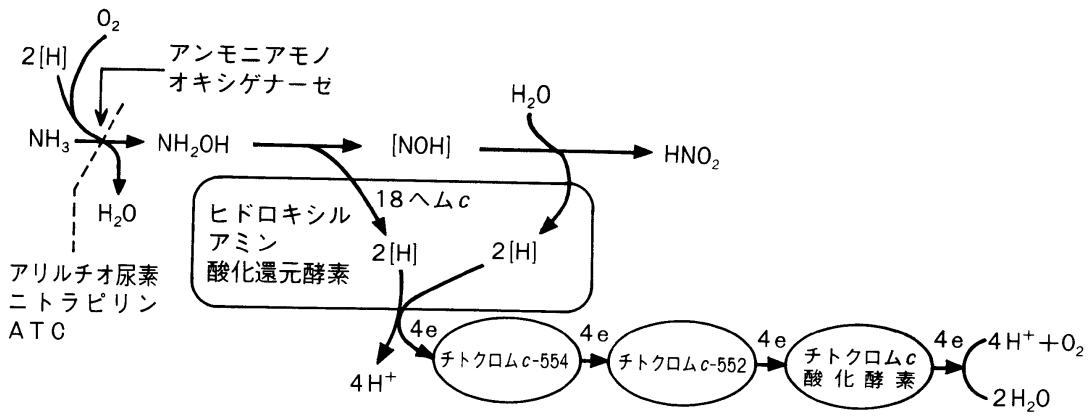

図 3. N. europaea におけるアンモ二アの亜硝酸への酸化系 ${ }^{3)}$ (アリルチオ尿素, ニトラピリン, ATC は硝酸化成抑制剤として用いられる農薬)

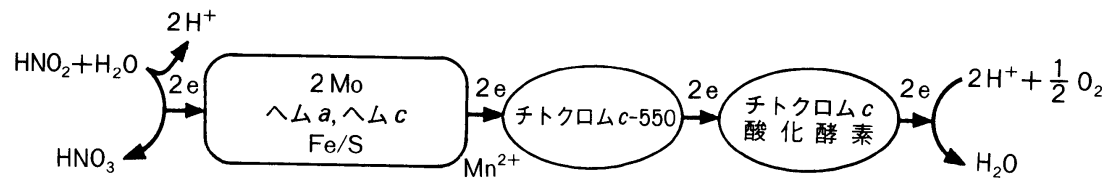

図 4 N. winogradskyi に护ける亜硝酸の硝酸への酸化系 ${ }^{18)}$

は, 八ロゲン炭化水素が漏れた場合，それをアンモニア 酸化細菌により処理してもら打らといらわけにもいかな いかもしれない。な拉, 残念ながら, テトラクロロエタ ンは N. europaea によっては分解されない。

さて, N. europaea によるヒドロキシルアミンの酸化 はかなりその機構がわかってきた。ヒドロキシルアミン は, ヒドロキシルアミン酸化還元酵素により脱水素され [NOH] なる中間体を経て亜硝酸になる。ヒドロキシル アミン酸化還元酵素は, 分子量 18-21 万のタンパク質で その中にへム $c$ 18-21 分子と P-460 とよばれる正体不明 のクロモフォアを 1-3 分子もっている11),12) (図 2)。化 学的にも鉄イオンの触媒作用でヒドロキシルアミンから 亜硝酸が生じるが，この場合はヒドロキシルアミンは $\mathrm{O}_{2}$ により酸化される。つまり生じた亜硝酸の中へ導入 された 2 番目の酸素原子は $\mathrm{O}_{2}$ から来る。ところがヒド ロキシルアミン酸化還元酵素によりヒドロキシルアミン から亜硝酸が生じるときは 2 番目の酸素は水から来る のである。すなわち，この酵素でヒドロキシルアミンを 酸化させる場合に, 多量の電子受容体（例えば酸化型 のチトクロム $c$ とかフェリシアン化カリウム $\left(\mathrm{K}_{3} \mathrm{Fe}\right.$. $\left.(\mathrm{CN})_{8}\right)$ とか) があると, たと充嫌気的条件下でもヒドロ キシルアミン $\left(\mathrm{NH}_{2} \mathrm{OH}\right)$ が亜硝酸 $\mathrm{HNO}_{2}$ への変化が起 こるのである14)。つまり $\mathrm{NH}_{2} \mathrm{OH} \rightarrow \mathrm{HNO}_{2}$ の反応で取り 込まれた酸素原子は水の酸素原子といらことになる。

$\mathrm{NH}_{2} \mathrm{OH}+\mathrm{H}_{2} \mathrm{O}+4 \mathrm{~K}_{3} \mathrm{Fe}(\mathrm{CN})_{6}$

ヒドロキシルアミン

$\stackrel{\text { 酸化還元酸素 }}{\longrightarrow} \mathrm{HNO}_{2}+4 \mathrm{H}^{+}+4 \mathrm{~K}_{3} \mathrm{HFe}(\mathrm{CN})_{8}$

このことは, 筆者ら ${ }^{14)}$ が見いだしたが, 後に Andersson
と Hooper ${ }^{15)}$ により ${ }^{18} \mathrm{O},{ }^{15} \mathrm{~N}$ を使った大がかりな実験 で確認された。

N. europaea によるアンモニアの酸化では亜硝酸 $(\mathrm{H}$ $+\mathrm{NO}_{2}^{-}$) が生じるので周囲が酸性になる。自然界では, アンモニア酸化細菌と亜硝酸酸化細菌が共存するが, 亜 硝酸酸化細菌, 中でも Nitrobacter winogradskyi は $\mathrm{pH}$ に敏感で, $\mathrm{pH}$ が 6 より低くなると順調に亜硝酸を酸化 できなくなるから注意を要する。土壌の $\mathrm{pH}$ が低下する と亜硝酸公害の起こりらることは後述する。

アンモニア酸化細菌によるアンモニアの酸化の際, 酸 素の供給が十分でないと亜酸化窒素 $\left(\mathrm{N}_{2} \mathrm{O}\right)$ が生じるこ とが知られている。亜酸化窒素はオゾン層を破壊するの で,この気体の発生も歓迎できない。従来は, ヒドロキ シルアミンから亜硝酸が生じる中間体 $([\mathrm{NOH}])$ からこ の気体が発生するように考光られていたが，アンモニア 酸化細菌に ${ }^{15} \mathrm{NO}_{2}{ }^{-}$を与えると ${ }^{15} \mathrm{~N}_{2} \mathrm{O}$ が生じるといら報 告があり, 一度生じた亜硝酸が還元されて亜酸化窒素が 生じるといら考えが強くなっている。しかし, アンモニ ア酸化細菌による亜酸化窒素の生成量は, 亜硝酸酸化細 菌を共存させてアンモニアの酸化で生じた亜硝酸を除去 しても変化しないという報告もあり, アンモニア酸化細 菌によるこのガスの生成機構はまだはっきりしない。い ずれにしても, アンモニア酸化細菌と亜硝酸酸化細菌に よる硝化に関しては十分な酸素の供給が必要である。ア ンモニア酸化細菌の代表格である Nitrosomonas europaea におけるアンモ二アの亜硝酸への酸化機構は図 3 に示すと拈りである。 


\section{2 悪硝酸酸化細菌}

アンモニア酸化細菌がアンモニアを酸化して生じた亜 硝酸は, 悪硝酸酸化細菌により酸化されて硝酸になる。 亜硝酸酸化細菌の代表例は Nitrobacter winogradskyi で ある。この細菌に和ける亜硝酸酸化の機構は大体明らか になった (図 4)。まず, “覀硝酸脱水素酵素”之もいうべ き酵素 (=チトクロム $\left.a_{1} c_{1}\right)^{16)}$ が $\mathrm{HNO}_{2}+\mathrm{H}_{2} \mathrm{O}$ から水素 (または電子) をうばう。この酵素は, 亜硝酸酸化還元酵 素と呼ばれるが, 1 分子中にへム $a$, へム $c$ をそれぞれ 1 分子, Moを 2 原子, それに $\mathrm{Fe} / \mathrm{S} ク$ クター（たぶ ん $\left.\mathrm{Fe}_{4} \mathrm{~S}_{4}\right)$ を 1 個もっている17)。この酵素は, 亜硝酸の存

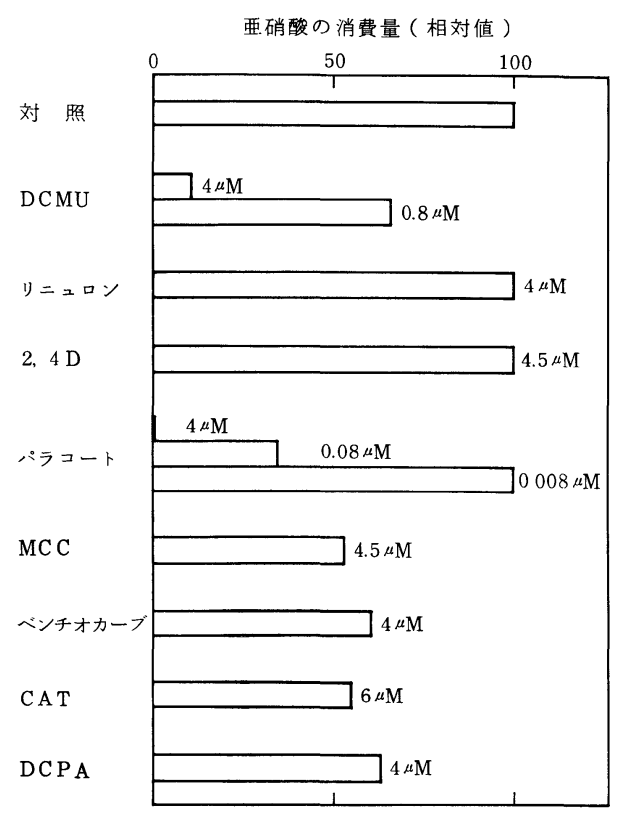

図 5 種々の除草剂による N. winogradskyi の生 育の阻害 ${ }^{3}$

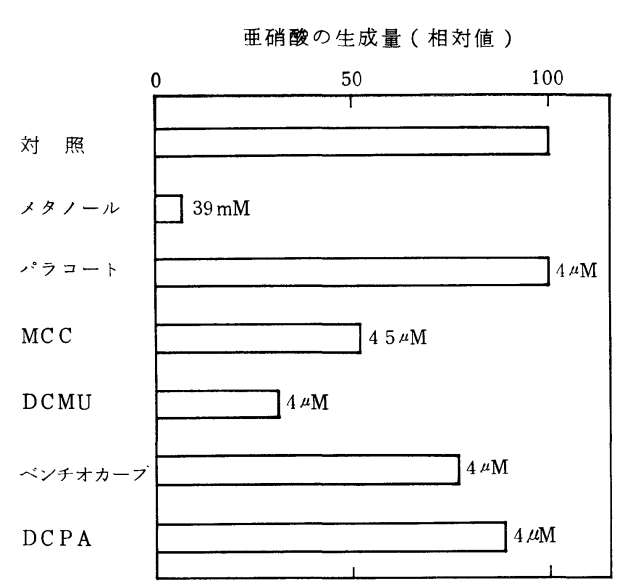

図 6 種々の除草剤による $N$. europaea の生育の 阻害 ${ }^{3}$
在下にチトクロム $c$ (酸化型) を還元するが, 酸化還元電 位の関係で, この反応は試験管内では非常にゆっくりと

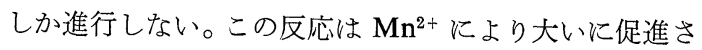
れる。また, この酵素による亜硝酸の酸化は, $\mathrm{pH} 8$ 付近 でスムースに進行するが, pH 6 以下では亜硝酸の酸化 が止まるだけでなく，この酵素が硝酸還元酵素に変化す る。つまり, 同じ酵素が, $\mathrm{pH} 8$ 付近では亜硝酸を酸化 し，pH 6 以下では硝酸を還元するのである。従って， この亜硝酸酸化還元酵素をもつ N. winogradskyi は, pH 8 では硝化細菌であるが, pH 6 以下では, いわば “脱窒菌”に変身することになる。亜硝酸酸化細菌に抒 ける亜硝酸酸化機構の分子レベルでの研究でわかったこ とは, この細菌による亜硝酸の酸化をスムーズに行わせ るためには, 環境の $\mathrm{pH}$ を 8 付近に維持すること, 通 気をよくすること，そして適量の $\mathrm{Mn}^{2+}$ の撤布が必要で あるといらことである。ところが, 最近, N. winogradskyi を培湌するとき $\mathrm{Mn}^{2+}$ を培地に加えると，この細菌の 硝化作用が阻害されるといら報告がなされた ${ }^{19) 。 ~}$

\section{3 除草剤亡硝化細菌}

すでに述べたように, アンモニア酸化細菌と亜硝酸酸 化細菌とを合わせて硝化細菌と呼ぶが, 除草剤の撒布が 硝化細菌の活動を抑制することはないだろらか。多くの 除草剤は多かれ少なかれ硝化細菌の生育を阻害する（図 $5,6)$ が，その阻害はやがて (1 週間位で)なくなり硝化 細菌はまた生育しだす。ところが，パラコートだけは例 外で, いつまでも亜硝酸酸化細菌の生育を強く阻害す る。しかし，この除草剤は亜硝酸酸化細菌の生育を阻害 すると同濃度 $(4 \mu \mathrm{M})$ ではアンモニア酸化細菌の生育を ぜんぜん阻害しない14)。

パラコートが除草剤になりらる原理は, それが NAD (P)-還元酵素系で還元されて次に酸素と反応して生物組

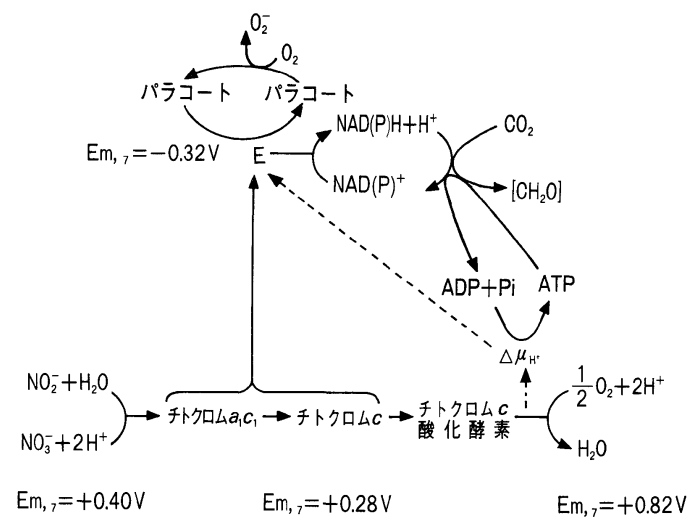

図 7 N. winogradskyi がパラコートを還元するこ とを示す模式図

$\left(\Delta \mu_{\mathrm{H}^{+}}\right.$は形質膜の両側間の $\mathrm{H}^{+}$濃度差によ り生じる電気化学ポテンシャル差) 


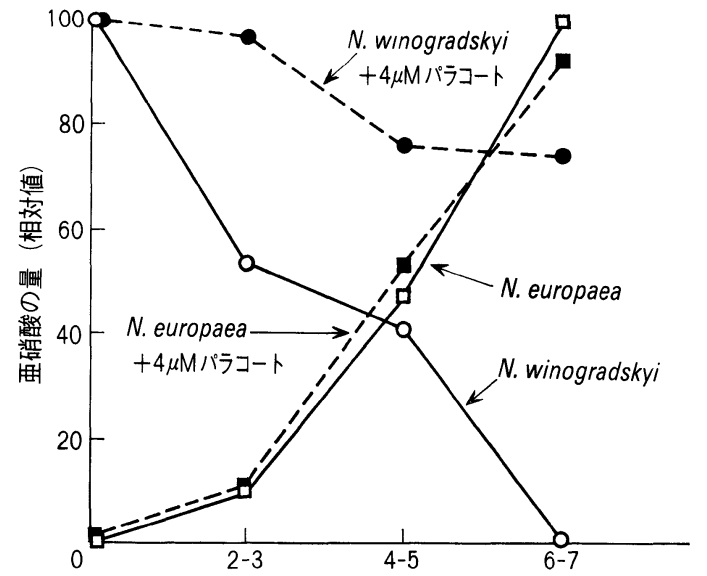

培養 時間（日）

図 18 N. winogradskyi と N. europaea の生育に 扣よぼすパラコートの影響3

(N. winogradskyi の生育が進めば亜硝酸が 減少し, N. europaea の生育が進めば亜硝酸 の量が増加する)

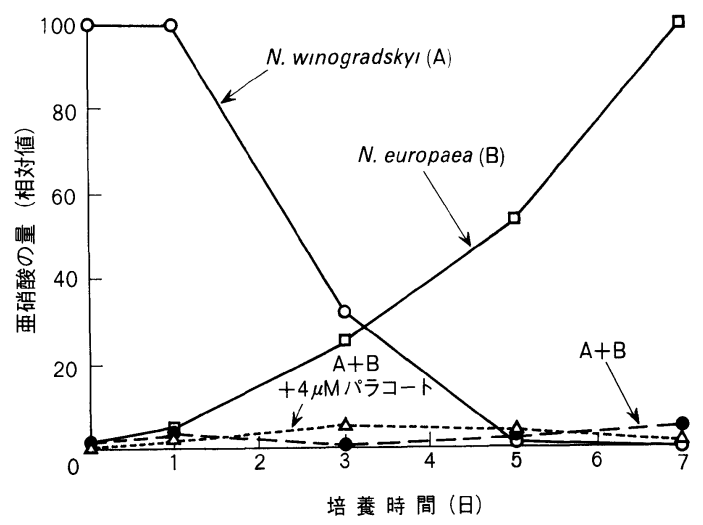

図 9 N. winogradskyi と N. europaea の混合培 養に対するパラコートの影響3

織にとって毒性の強いスーパーオキシドアニオン $\left(\mathrm{O}_{2}^{-}\right)$ を生ずるといらことであるから, 同じょらに $\mathrm{NAD}(\mathrm{P})$ 還元酵素をもっている独立栄養化学合成細菌に対しても パラコートが有害に㗢くわけである(図 7)。むしろ, ア ンモニア酸化細菌が比較的パラコートに強いことの方が 理解に苦しむ点だが，この細菌に和けるアンモニア酸化 の中間体であるヒドロキシルアミンが $\mathrm{O}_{2}^{-}$のスカヴェ ンジャーとして働く可能性が高い。

ところで, パラコートのように, アンモニア酸化細菌 の生育は阻害しないが亜硝酸酸化細菌の生育を阻害する 除草剤は, 亜硝酸公害を引き起こすのではないかと心配 される。ところが, アンモニア酸化細菌と亜硝酸酸化細
菌の等量混合培養にパラコートを添加しても, 亜硝酸は ぜんぜん蓄積しないのである ${ }^{20)}$ (図 8,9)。自然界には両 細菌が注注等量生育しているため, パラュートの撒布に より亜硝酸の蓄積は起こらない。われわれは,この自然 のすばらしい“力”により助けられているわけである。 しかしながら, 非常に高濃度のパラコートはアンモニア 酸化細菌の生育までも阻害するため, 亜硝酸は蓄積しな いが窒素循環全体を阻書することになるので注意を要す る。

\section{4 亜硝酸公害}

すでに述べたよらに，亜硝酸酸化細菌の生育は阻害さ れるのにアンモニア酸化細菌の生育が阻害されないよう な環境では, 亜硝酸の蓄積が予想される。しかし, 上述 のように, アンモニア酸化細菌と亜硝酸酸化細菌がバラ ンスのとれた生育をしていると, 济とんどの場合, 亜硝 酸の蓄積を見ずにすむ。ところが，世界中でただ一度だ け亜硝酸公害が起こったことがある。1962 年, 高知県南 国市周辺で, 数日にしてハウス内の作物が枯れてしまっ たことがある ${ }^{21)}$ この場合, ハウス内にできた水滴中に は高濃度の亜硝酸が溶けていた。つまり, ハウス内の空 気中には, 二酸化窒素などの有害ガスが充満して, この ガスが作物を枯らしたのであった。いろいろ調べた結 果, このような事態にいたったのは, 一時に窒素肥料を 与えすぎたためだといら結論が得られた。例えば, 尿素 のような窒素肥料を多量に与えると，N. europaea の活 発な活動の結果, 多量の亜硝酸が生成する。亜硝酸が生 成すると土壤の $\mathrm{pH}$ が低下するため, N. winogradskyi による亜硝酸の酸化が抑制されるが，ささにも述べたと おり, 硝酸の亜硝酸への還元まで促進される。そして,

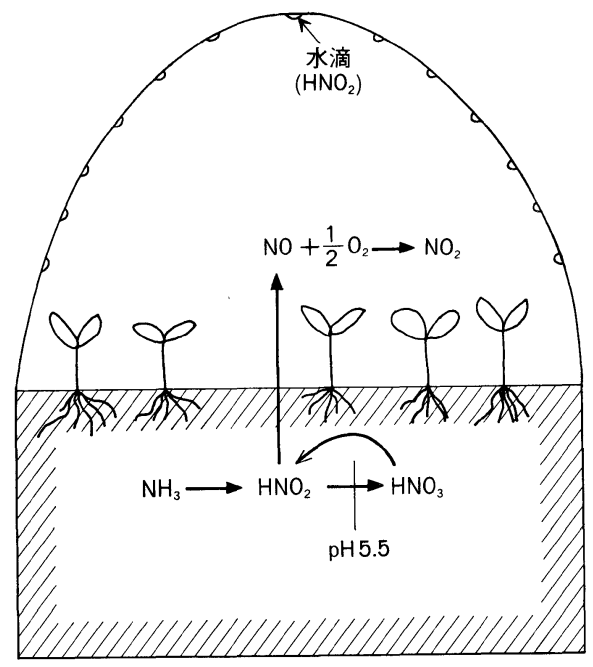

図 10 ハウス内の作物が亜硝酸公害で被害を被。 た場合の模式図 
亜硝酸が蓄積した土壤の $\mathrm{pH}$ が 5.5 くらいまで低下する と亜硝酸が分解して NO が生じ, NO は $\mathrm{O}_{2}$ と反応して ただちに $\mathrm{NO}_{2}$ になり，これが作物を枯らしたわけであ る(図 10)。このできごとは消石灰で土壤の $\mathrm{pH}$ を上げる ことにより防止できることがわかり，その後このような できごとは起こっていないよらである。

自然界では, たとえ亜硝酸が蓄積して二酸化窒素が発 生しても，作物がこのよらな被害にあらことはないであ ろらが，八ウスのような閉鎖系では亜硝酸の蓄積による 害が起こりやすいことを上述のできごとは示している。 がななよりも注意すべきは，たと元自然界であっても， アンモニア酸化細菌と亜硝酸酸化細菌がバランスのとれ た生育をしていないと亜硝酸による公害が起こりらると いうことである。

\section{5 脱 窒}

硝化細菌の作用でアンモニアが酸化されて生じた硝酸 は, 植物に吸収されるが, 残りは脱窒菌により窒素ガス となり大気中へ放出される。こうなれば，アンモニア污 染は完全に浄化されたことになるが，植物の利用できる 窒素（固定化窒素）はなくなり，施肥といら立場からは 窒素肥料の大損失ということになる。従って，脱窒を阻 止したいといら立場もあるわけだが，脱窒を阻止するこ とは非常に困難である。脱窒による固定化窒素の損失を 防ぐには，現在のところ，アンモニア酸化細菌によるア ンモニアの酸化を阻止するしか方法がない。すなわち, 硝化抑制剂を撒くわけだが，これは窒素循環をいわば根 もとで止めてしまうことになるので感心しない。

脱窒菌は有機物を硝酸塩 [抒よびその還元生成物（亜 硝酸, 酸化窒, 亜酸化窒素)] で酸化して生育に必要なエ ネルギーを得るわけだが，その際硝酸塩は還元されて窒

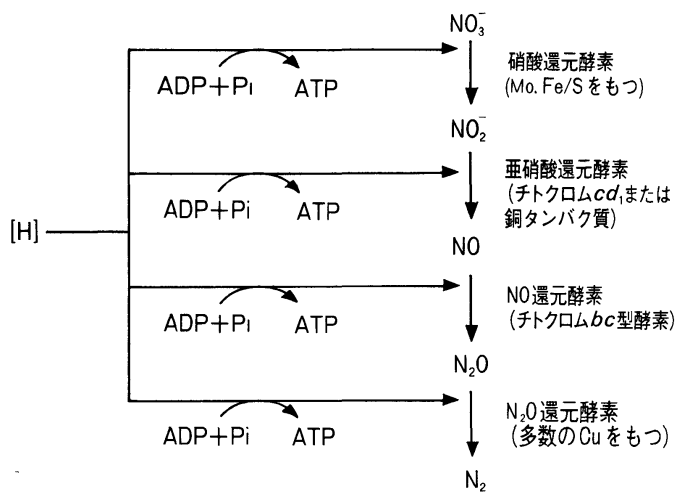

図 $11 \quad \mathrm{NO}_{3} \rightarrow \mathrm{N}_{2}$ 型の硝酸塩呼吸の各素反応の関 係を示す 33

(Pi は無機りン酸, $[\mathrm{H}]$ は有機化合物（無機 物の場合もある) から抜き取られた水素（ま たは電子) が何らかの形で供給されること を示す)
素ガス $\left(\mathrm{N}_{2}\right)$ あるいは亜酸化窒素 $\left(\mathrm{NO}_{2}\right)$ になる (図 11)。

脱窒菌は, 図 11 に示すように, 硝酸塩を数段を経て 窒素ガスに還元し，その間に ATP をつくる。硝酸塩て 有機物を酸化して ATP を生成するということに重きを 括くときは，この反応は硝酸塩呼吸とよばれる。脱窒と いら場合は窒素の動きのみに注目しているといえる。脱 窒の最後の段階， $\mathrm{N}_{2} \mathrm{O} \rightarrow \mathrm{N}_{2}$ の反応を触媒する亜酸化窒 素還元酵素は銅酵素でまた $\mathrm{O}_{2}$ に対して弱いため，環境 に銅が足りないか $\mathrm{O}_{2}$ が少し存在するかすると，硝酸塩 が窒素ガスにまで還元されずに亜酸化窒素が放出される ことになる22, 23)。先にも述べたと扮り，亜酸化窒素はオ ゾン層を破壞するので，亜酸化窒素を出さずに脱窒が起 こる条件をととのえる必要がある（もっとも，順調に脱 窒が起こっているときでも窒素がスに混ざって少量の黃 酸化窒素が出る)。脱窒を阻害するためにはシアン化物 などの強烈な毒物を与光る必要があるが， $\mathrm{N}_{2} \mathrm{O} \rightarrow \mathrm{N}_{2}$ の 過程はアセチレンで強く阻害される ${ }^{24)}$ 。

\section{6 窒素固定}

脱窒により硝酸 窒素ガスの反応が起こると，地球の 生物圈の固定化窒素が不足する。しかし，自然界には， 脱窒により失われた固定化窒素を，また取り戻してくれ る細菌がいる。窒素固定をする細菌である25)。だからこ そ, 地球の生物圈に打汗る固定化窒素のバランスがとれ ている。もっとも，これには硫安製造といら人工的窒素 固定も一役かっているが。しかし，こういら人工的に固 定した窒素化合物を撒布する量が多くなれば，細菌によ る窒素固定量が減少することになる。硫安等の窒素肥料 を撒布するより，生物による窒素固定で固定化窒素の量 を増す注らが自然界を荒さずにすむわけだが，生物によ る窒素固定のみではまどろっこしく，化学的窒素肥料を 与えるほうがはるかに農産物の増収につながるというの が現状であるう。しかし，熱帯地方のように，硫安を与 えてもすぐ硝化, 脱窒が起こり窒素肥料が消失する場合 は，生物的窒素固定によるか，硝化抑制剂の撒布をする かが必要にならら。硝化抑制剤の撒布はあまりよい方策 とはいえない。

なお，自動車の排気ガスや工場の煙突からの排煙中に 含まれる窒素酸化物（窒素固定とはい党ないが）も植物 の窒素源となることがある。しかし，これらは硝酸など の酸を生ずるため, 土壌の中和能力の限界を越えると土 壤や湖水を酸性にするので，いただけない。それどころ か大公害の原因となる。もし, 酸性で働く脱窒菌があれ ば，窒素酸化物による酸性化の公害は防げるであろう。

\section{3. 硫黄の循環}

硫黄の循環に関しても微生物が深くかかわっている。 たとえば，水田に肥料として撒布された硫安のアンモニ 


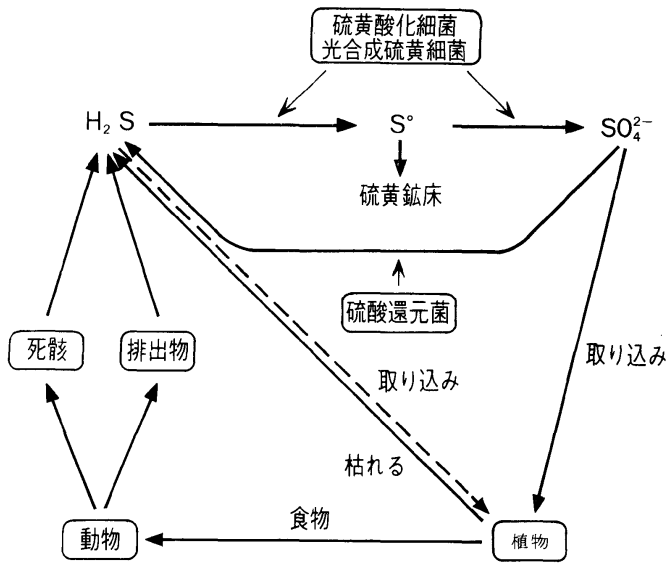

図 12 自然界に打子る硫黄の循環 3

$\left(\mathrm{H}_{2} \mathrm{~S}\right.$ をとり込む植物のなかにはカビや図中に記さ れなかった細菌などを含むため点線で記してある)

ウムイオンはイネに吸収され，残った硫酸イオンは還元 的環境のもとでは硫化水素になりイネの根をおびやか す。硫化水素は空気のあるところへ移動すると硫黄酸化 細菌の作用で硫酸になり，例えばコンクリート製の物体 や石像を破壊することがある。硫黄化合物の酸化還元に 関与する微生物は環境の保全にはあまり関係がなく環境 を破壊するだけのよらにも思える。しかし，ある場所で は硫化水素を酸化して，それによる環境の污染をくいと めている場合もある。

硫黄の循環においても, 硫黄鉱床になったものは一時 的に循環からはみ出しているといえる。しかし，それも やがて酸化されて硫酸などになれば循環の中に入ってゆ <(図 12)。

\section{1 硫酸還元菌}

嫌気的条件下で，有機物を硫酸塩で酸化して，その際 生じるエネルギーを利用して生きている細菌がいる。硫 酸還元菌である ${ }^{26)}$ 。硫酸還元菌の行う，有機物を硫酸塩 で酸化するエネルギー獲得方法は, 硫酸塩呼吸とよばれ

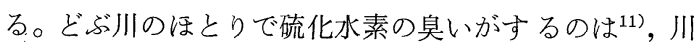
底で硫酸還元菌が活発に活動しているからである。水田 でも硫化水素が発生して, 開花期のイネが枯れる (秋落) ことがあったが，土用干によりできるだけ水田の土壌に 空気を導入することで，これは防げるよらになった。硫 酸還元菌が絶対嫌性細菌であることがわかったからであ る。

\section{2 硫黄酸化細菌}

元素硫黄や硫化水素, さらにはパイライト $\left(\mathrm{FeS}_{2}\right)$ の ような硫黄化合物を酸化する硫黄酸化細菌がいる。この 細菌は, 露天掘の炭田に雨水が溜ると盛んに活動して石 炭中の元素硫黄層やパイライト層を酸化して硫酸をつく る。この硫酸が河川に流れ込むと酸性公害が生じる。
このような硫酸の生成は炭田に限ったことでなく, 硫化 鉱床を含む鉱山からの湧水中にも硫黄酸化細菌（および 鉄酸化細菌）の作用により生成した硫酸が多量に溶けて いるのが普通である。

硫黄酸化細菌と硫酸還元菌の共同作用でコンクリート などが破壊されることもある。コンクリート製の下水管 では，下水から発生した硫化水素が下水管の天井内部に 浸透し, 天井の外部から雨水が浸透すると，そこで硫黄 酸化細菌の活動が始まり，生じた硫酸が下水管の天井な いしはふたを破壊することがある。また，熱帯地方の湿 地帯に建てられた石像が根元から折れることがある。こ れも硫酸還元菌の活動で地中で発生した硫化水素が上昇 して空気と触れるあたりで硫黄酸化細菌により酸化され 生じた硫酸により石像が侵食されて折れるのである ${ }^{26)}$ 。 このよらな現象を見ると, 硫黄酸化細菌は環境保全には あまり役立っていないようである。しかし，硫化水素を 酸化する光合成細菌は，次に述べるように環境保全に役 立っている。

\section{3 光合成硫黄細菌}

光合成細菌の中には, 硫化水素や元素硫黄を酸化する ものがある。緑色硫黄細菌や紅色硫黄細菌がそれであ り，光合成硫黄 (酸化) 細菌とでもいらべき細菌である。 水深が $20 \mathrm{~m}$ 以上あるような深い湖の湖底では, 多く の場合, 硫酸還元菌が活動しており硫化水素が生成して いる。しかし, 溶存酸素の濃度がほとんぞ 0 になる湖面 下 $15 \mathrm{~m}$ くらいのところに光合成硫黄細菌が生息してい て硫化水素を酸化していることが知られている27) (図 13)。その抢かげで湖面近くの湖水は硫化水素により污 染されることがない。これは, 硫化水素を酸化する光合 成硫黄 (酸化) 細菌による還境保全の一例である。

また, アフリカのある湖では湖水が硫酸カルシウムで 飽和されて扣り，湖底で硫酸還元菌がこの硫酸塩を還元

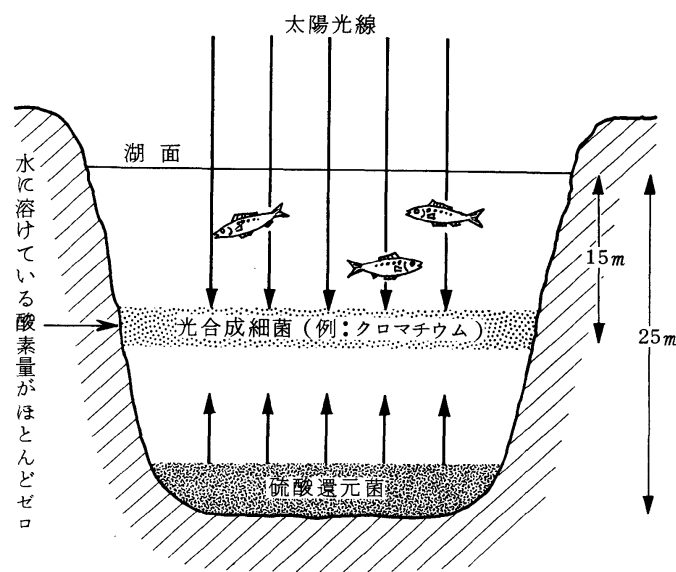

図 13 湖底から発生する硫化水素とそれを食べる 光合成細菌の関係 ${ }^{1)}$ 
して盛しに硫化水素を生成している。しかし，湖面には 光合成硫黄細菌がマット状に生育していて上昇してくる 硫化水素を強い太陽光線を利用して元素硫黄に酸化して いる ${ }^{26)}$ 。このような反応で元素硫黄が次第に蓄積してゆ く。現在, アメリカ合衆国などに存在する硫黄鉱床は $2 \sim 3$ 億年昔にこのよらにして形成されたものだと考兄 られている。この湖の場合, 光合成細菌がいなければ多 量の硫化水素が湖水中和よび大気中に放出されて周囲が 硫化水素で污染されるのだが，光合成細菌の活動の招か げで，硫化水素による污染が防がれているわけである。

\section{4. 炭素の循環}

炭素の循環は地球環境の保全に最も深くかかわってい るだろう。二酸化炭素は, 動物や光合成能のない植物に よる有機物の酸化で生じるほか，工場などに打ける有機 物の然焼, 車などのエンジンに特ける燃焼によっても多 量に排出される。中でも従属栄養微生物による有機物の 分解によって多量に生成するが，この微生物による有機 物の分解がなければ，地表は多量の有機物で覆われ身動 きがならなくなるであろら。そして，二酸化炭素は地球 温暖化の原因としてきらわれものになっているかの観が あるが二酸化炭素が 適当量ないと植物の光合成が順調 に進行しなくなる。とすると動物の必要な分子状酸素 $\left(\mathrm{O}_{2}\right)$ がつくられないといらことになる。炭素の循環にお いても過去に植物が石油と石炭になったものは一時循環 からはみ出したことになる。しかし，これは現在では然 焼されて大量の二酸化炭素となり炭素循環の中へ加わっ ている（図 14）。もっとも, 石油, 石炭は植物から生じ たものではないといら考えもある28)。

\section{1 二酸化炭素の消費}

二酸化炭素を消費する主役は，何といっても緑色植物 (光合成の結果 $\mathrm{O}_{2}$ を放出する植物)である。その中には

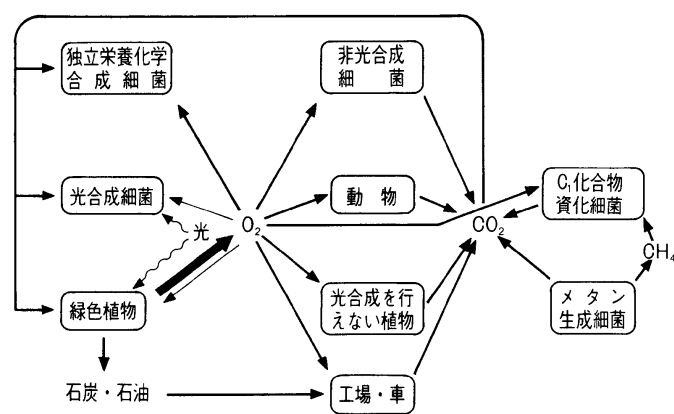

図 14 自然界に抢ける炭素の循環 (非光合成細菌の中で嫌気性細菌は $\mathrm{O}_{2}$ を必要としな いし， $\mathrm{C}_{1}$ 化合物には $\mathrm{CO}_{2}$ は含めていない。また独 立栄養化学合成細菌は生きている間は $\mathrm{CO}_{2}$ を出さ ない。なお， $\mathrm{CH}_{4}$ は一部分大気中に放出される)
藻類がふくまれるので, 微生物による二酸化炭素の消費 に大いに関係していることになる。二酸化炭素の消費の 80-90\% は海洋で行われているともいら28)。乙かし，二 酸化炭素の消費に扣いては藻類だけ（つまり微生物だ け）が重要なのではなく，陸上の高等植物，つまり草や 木が大きな役割を果たしている。従って，ここでは，光 合成による二酸化炭素の消費は上述の上らに高等植物の 他に藻類も行っていることを述べるにとどめる。

\section{2 メタンの生成}

二酸化炭素の消費量からすると緑色植物による光合成 にはとても拉よばないが，細菌によるメタンの生成も二 酸化炭素の消費を伴う。しかし,メタンも温室効果のあ る気体なのだから，その生成は光合成におけるように二 酸化炭素を消費して動物などの好気性生物飞必須な分子 状酸素をつくるのとはわけが違う。それなりに，メタン の生成は環境保全といら面からは考皃なければならない 問題をかかえている。

メタン生成細菌は, 水素を二酸化炭素で酸化して，そ の結果メタンを生成するが, 細菌によっては, メタノー ル, メチルアミン, ギ酸, 酢酸からもメタンを生成する。 メタン生成細菌は絶刘嫌気性細菌だから，どぶ川や沼な ぞの底泥中に生息し，他の嫌気性細菌が有機分解物をし て生ずる水素と二酸化炭素, あるいはメタノールなどを 利用する。したがって，メタン生成細菌は，一般的にい って，他の嫌気性細菌と（外部）共生をしている。メ夕 ンは温室効果があるので自然界でのそれの発生は歓迎さ れないが，メタン生成細菌のメタン生成過程そのものは

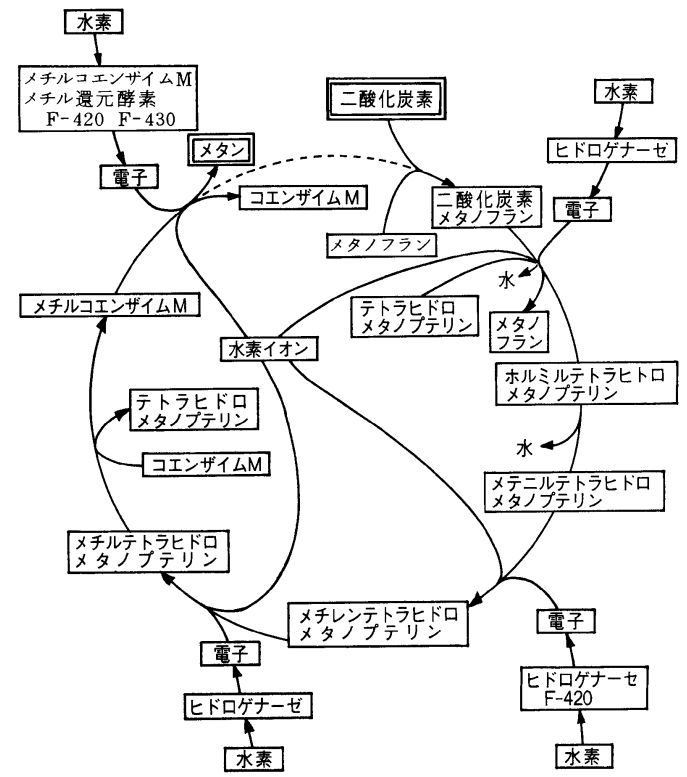

図 15 メタンの生成機構を模式的に示したもの1) 


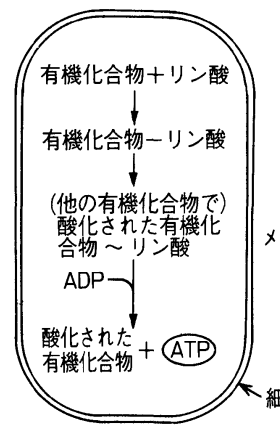

(a) 発醅におけるATPの生成

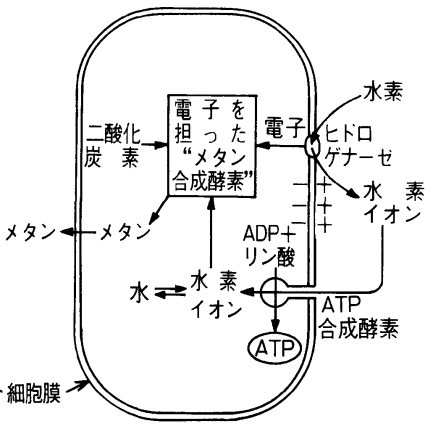

(b) メタン発生にともなうATPの生成
図 16 発酵 (a) とメタン発生 (b) とは ATP ので き方がちがうことを示す1)

(〜リン酸は ATP 合成に必要なだけのエネルギー をもつリン酸結合, “メタン合成酵素” は図 15 に示 したように多種類の酵素の集まり)

嫌気的条件下で有機物の分解を促進して拉り, 環境の浄 化に役立っているのである。したがって，メタン生成細 菌を用いて污水处理ができるわけである。

メタン生成細菌に和けるメタン生成の機構は, 最近に

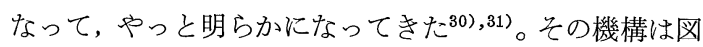
15 に示すようなものであるが，そこには他の生物には 見られない物質がいろいると関与している。因子 $F_{430}$ (補酵素 $\mathrm{F}_{430}$ という核うがよい), 補酵素 $\mathrm{M}$, メタノフ ラン,メタノプテリンなどがそれである。メタン生成細 菌の細胞内の ATP 量は, メタンの生成につれて多くな る。つまり, メタン生成細菌がメタンを生成するのは, この細菌が生きてゆくために必要なエネルギー源である ATPをつくるためである。ところが, メタン生成細菌に 和牧るメタン生成に共役した ATP 生成方法は，すべて 呼吸に和忷るATP の生成方法であり, 発酵に打ける ATP 生成方法はぜんぜん見あたらないのである(図 16 $\mathrm{a}, \mathrm{b})$ 。つまり, 発酵においては, ATP を生成するのに途 中で必ず有機化合物のリン酸化合物が生成する。ところ が, メタン生成菌の ATP 生成においては, 有機化合物 のリン酸化合物はぜんぜん生じない。ATP 生成反応の 阻害物に対する挙動などから, メタン生成細菌に持ける ATP の生成機構は, 呼吸に和けるの同じであることが わかった。従って, メタン生成細菌に括けるメタンの生 成は, メタン発酵ではなく, 二酸化炭素呼吸と呼ばれる ことになった ${ }^{30)}$ 。

先にも述べたように, アンモニア酸化細菌はアンモニ アとメタンの構造が似ているため, メタンを酸化するこ とができる22)。アンモニア酸化細菌は, メタンをメタ, ールにまで酸化するが, メタノールをさらに酸化するこ とはできない。けれども, アンモニア酸化細菌と同じ場 所に $\mathrm{C}_{1}$ 化合物資化細菌が生息していると，それが生じ

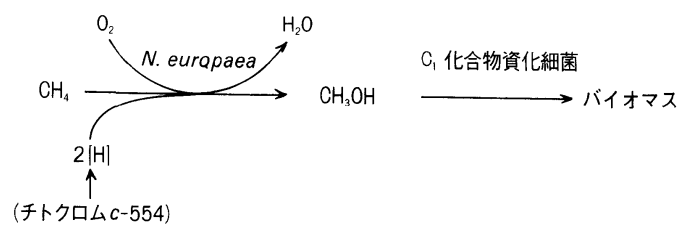

図 17 N. europaea と $\mathrm{C}_{1}$ 化合物資化細菌々の共 同作用でメタンを消費できることを示す模 式図

たメタノールを利用してくれる（図 17）。そらなればメ タンがバイオマスに吸収されることになり空気中に放出 されなくてすむ音。従って,アンモ二ア酸化細菌と $\mathrm{C}_{1}$ 資 化細菌が一緒に生息していると, メタンの放出を防いで くれる。しかし, この場合, ある程度のアンモニアがな いとメタンの酸化がスムーズに進行しないが，一方アン モニアが多すぎると，アンモニア酸化細菌はアンモニア ばかり酸化してメタンを酸化しなくなるので注意を要す る。

\section{5. おわりに}

地球の表面には, 膨大な種類の微生物が生息していて 環境の保全や污染に関係しているが, 本小文では, 特に, 窒素, 硫黄, 炭素の循環に深いかかわりをもつ微生物を とりあげ，それらと地球環境との関係を述べてみた。こ れらの元素の循環に微生物が密接に関係していることを 知っていただき,さらに, これを機会に微生物と地球環 境との関係を，一層深く理解していただければ幸であ る。

\section{(1991 年 8 月 23 日受理)}

\section{文献}

1）山中健生：「無機物だけで生きてゆける細菌」, 共 立出版 (1987).

2) H. G. Schlegel \& B. Bowien (eds.): "Autotrophic Bacteria", Science Tech Publishers, Madison, Wisconsin (1989).

3) 山中健生：「入門生物地球化学」, 学会出版センタ 一 (印刷中).

4) T. Hofman \& H. Lees: Biochem. J., 54, 579 (1953).

5) I. Suzuki, S. C. Kwok, U. Dular \& D.C. Tsang: Can. J. Biochem. 59, 477 (1981).

6) A. B. Hooper \& K. R. Terry: J. Bacteriol., 115, 480 (1973).

7) I. Suzuki, S. C. Kwok \& U. Dular: FEBS Lett., 72, 117 (1976).

8) C. Bédard \& R. Knowles: Microbiol. Rev., 53, 68 (1989).

9) M.E. Rasche, R. E. Hicks, M. R. Hyman \& D. J. Arp: J. Bacteriol. 172, 5368 (1990).

10) T. Vannelli, M. Logan, D. M. Arciero \& A. B. Hooper: Appl. Environ. Microbiol., 56, 1169 
(1990)

11) A. B. Hooper, P. C. Maxwell \& K. R. Terry: Biochemistry 17, 2984 (1978).

12) T. Yamanaka, M. Shinra, K. Takahashi \& M. Shibasaka: J. Biochem. 86, 1101 (1979).

13）山中健生：表面 27, 881 (1989).

14) T. Yamanaka \& T. Sakano: Curr. Microbiol. 4, 239 (1980).

15) K. K. Andersson \& A. B. Hooper: FEBS Lett., 164, 236 (1983).

16) Y. Tanaka, Y. Fukumori \& T. Yamanaka: Arch. Microbiol. 135, 265 (1983).

17) M. Fukuoka, Y. Fukumori \& T. Yamanaka: J. Biochem. 102, 525 (1987).

18) T. Yamanaka \& Y. Fukumori: "Recent Advances in Microbial Ecology" (T. Hattori, Y. Ishida, Y. Maruyama, R. Y. Morita \& A. Uchida, eds.) p. 211, Japan Scientific Societies Press, Tokyo, (1989).

19) 岡 紀邦, 和田秀德: 日本土䁃肥料学雑誌, 62, 95 (1991).

20) T. Yamanaka: Plant Cell Physiol., 24, 1349 (1983).

21）西尾道徳：「土の微生物」(土壤微生物研究会編), p. 109, 博友社 (1981).
22) H. Iwasaki, T. Saigo \& T. Matsubara: Plant Cell Physiol. 21, 1573 (1980).

23) L. I. Hochstein, M. Betlach \& G. Kritikos: Arch. Microbiol., 137, 74 (1984).

24) M. P. Stephan, W. Zimmer \& H. Bothe: Arch. Microbiol., 131, 19 (1984).

25) J. R. Postgate: "Nitrogen Fixation", E. Arnold Ltd., London (1978) [邦訳：庄野邦彦,「窒素固 定」, 朝倉書店 (1981)].

26) J. R. Postgate: "The Sulphate-Reducing Bacteria", Cambridge University Press, London (1979).

27）北村 博：「微生物の生態（5）環境污染をめぐっ て」(微生物生態研究会編), p. 85, 学会出版セン ター (1978).

28） T. ゴールド：「地球深層ガス」(脇田宏訳)，日経 サイエンス社 (1988).

29） H. ゲスト：「微生物の世界」(高桑進訳), 培風館 (1991).

30) L. Daniels, R. Sparling \& G. D. Sprott: Biochim. Biophys. Acta 768, 113 (1984).

31) M. I. Donnelly \& R. S. Wolfe: J. Biol. Chem., 261, 16653 (1986).

32) M. R. Hyman \& P. M. Wood: Biochem.J., 212, 31 (1983). 